\title{
CIVILIZACINIS NEĮGALUMAS IR JO RAIŠKOS LIETUVOJE BRUOŽAI
}

\author{
Romualdas Grigas \\ Lietuvos mokslų akademijos narys emeritas \\ Architektų g. 91-55, LT-04207 Vilnius, Lietuva \\ Tel. +370 68734550 \\ El. paštas: romualdasgrigas@gmail.com
}

Pateikta 2014 m. liepos 16 d., parengta spausdinti 2014 m. rugpjūčio 8 d.

doi:10.13165/SMS-14-6-2-01

Anotacija. Straipsnyje demesys sutelkiamas $i$ viena iš rimčiausiu socialinès bei politinés organizacijos problemu - $i$ vadinamaji civilizacini neigaluma, $i$ šio reiškinio sklaidos Lietuvoje, lietuvių tautoje bruožus. Civilizacinis neigalumas autoriaus pateikiamas (interpretuojamas) kaip tautos ir jos pagrindu sukurtos valstybés elgsenu erdves, kurios užpildomos vieno ar kito masto pertekliniu susipriešinimu, deviacija, šešéliškumu, nusikalstamumu, išminties ir tęstinumo stokojančiais (strategiškai neapgalvotais) veiksmais. Socialinis neigalumas skatina anomijos, socialinès aritmijos, socialinio nuovargio sklaidą; suponuoja ir užlaiko vadinamaja „klaidinga sąmonę ir pan.

Autoriaus nuomone, civilizacinis neigalumas nèra kokia nors vienos tautos išskirtinybe. Tačiau kiekvienoje šalyje jis turi savo išskirtinius bruožus. Jie būna nulemti istorinio palikimo ir jo santykio su nüdienos moderniuoju pasauliu, su globalizacija ir jos šešéliais. Autorius taip pat kreipia dèmesị ir ị Lietuvos santykio su ES prasmingumą.

Reikšminiai žodžiai: civilizacinis pajëgumas, civilizacinis neigalumas, socialine organizacija, tautodara, tautoira.

Socialinių mokslų studijos / Societal Studies

(C) Mykolo Romerio universitetas, 2014

(C) Mykolas Romeris University, 2014
ISSN 2029-2244 (online)

http://www.mruni.eu/lt/mokslo_darbai/SMS/ http://www.mruni.eu/en/mokslo_darbai/SMS/ 


\section{Ivadas}

Savikritiškai vertinant, sumanymas kalbėti apie civilizacinį neigalumą, juolab apie lietuvių tautos atveji, yra gana rizikingas tiek teorine, metodologine, tiek ir empirine prasmèmis. Kaip apibrèžti pamatines sąvokas: civilizacinis pajègumas, civilizacinis neigalumas? Kokias prasmes jos turètų išreikšti? Kokiais kriterijais ar hipotezėmis apibrěžiamos ribos tarp vadinamojo civilizacinio pajègumo ir civilizacinio neịgalumo? Valstybių ir tautų kultūros ir jų istorijos yra ganėtinai skirtingos. Tai reiškia, jog ir pats jų civilizuotumas, jo raiška turi skirtingus kodus bei prasmes. Taigi, kas gali būti modeliu kalbant apie civilizacinị pajègumą (normalumą)?

Bet žinome: filosofiné, sociologine arba kad ir politinės antropologijos mintis nelinkusi pasiduoti kanonų diktatui; ji šalinasi iš „draustinių“ ir nuolat atsinaujindama siekia žengti koja kojon su šuoliuojančia civilizacija. $\mathrm{Na}$, o tai, kad visur, visuose socialinès organizacijos lygmenyse civilizacinio neigalumo aptinkama, rodo nuolat ir nuolat panašia ar artima jai tematika publikuojami veikalai. Paminèsiu tik keletą pasaulini pripažinimą ịijusių autorių: Zbigniew Brzezinski (Nebevaldomas pasaulis, 1998), George Soros (Pasaulinio kapitalizmo krize, 1999), Harold J. Berman (Teise ir revoliucija, 1999), Horst Kurnytcky (Necivilizuota civilizacija, 2002), Manuel Castells (Tinklaveikos visuomenès raida, 2005), John Gray (Apgaulinga viltis, 2006) ir t. t. Sąmoningai paminejjau tuos autorius, kurie tapo prieinami plačiajai Lietuvos visuomenei.

Lietuvių autoriai taip pat netylèjo (ir netyli). Vèlgi dèl įdomumo nurodysiu tik keletą: Algimantas Matulevičius (Valstybès valdymo užkulisai, 2008), Kęstutis Jaskelevičius (Valstybès atėmimas, 2010), kol. monografija - Valstybè žmogaus širdyje (tautos ir valstybès atskirtis, 2011); Viktorija Daujorytė, Aleksandras Vasiliauskas, Arvydas Šliogeris (Nerimas, 2013); Irmina Matonyte, Vaidas Morkevičius (Elitų Europa: tapatybių ir interesų kaleidoskopas, 2013).

Tai, ką mes randame išvardintų autorių veikaluose, patvirtina ypač aktyvų doméjimąsi šešèlinèmis šiuolaikinès civilizacijos ir jos raiškos atskirose šalyse pusèmis. Ir įsitikiname, kad tai - ne epizodiniai ar fragmentiniai atskirų visuomenės gyvenimo sričių reiškiniai, bet reiškiniai, turintys sistemini pobūdị, t. y. iš vienos socialinio organizmo dalies persiliejantys ị kitą, ir atvirkščiai. İžymus sociologijos žinovas JAV profesorius R. Mertonas yra akcentavęs: pagrindinè sociologijos (ir kitų jai artimų mokslų) užduotis - atskleisti latentines, t. y. šešélines, socialinio pasaulio, jo raiškos puses.

Išsamesnis, labiau susistemintas praeities ir ypač dabarties žinojimas tam tikru laipsniu visuomenę išvaduoja iš ateities primetamų pančių; tarsi prožektoriaus spinduliu nušviečia ateities perspektyvą: kokia ji bus? Ir kaip reiktų elgtis, kad ji bent kiek būtų šviesesnè, tobulesnè...

\section{Civilizuotumo apibrèžties prieigos: tauta ir jos egzistencijos tikslas}

Kaip jau buvo užsiminta, mąstant apie civilizacinị neigalumą, susiduriama su daugybe nežinomųjų. Vienas iš jų - pamatinio, viską persmelkiančio ir j̨žvalgas vie- 
nijančio kriterijaus problema. Bet prieš atsakant ị ši ne tik painų, bet ir nepopuliarų tapusị klausimą, mesime trumpą žvilgsnị tautos link...

Tautos esmé, jos būtis apibūdinama labai ịvairiai. Ji, pritariu B. Andersono nuomonei - „isivaizduojama konstrukcija“. Bet čia pat ir prieštarauju. Tauta - egzistuojanti konstrukcija. Jos egzistavimą rodo ir materialieji, ir idealieji paminklai. Ji, kaip ir Dievo (Absoliuto) esatis, yra sklandanti, mus užvaldanti dvasia. Tauta neturi savo kontūrų apibrèžties. O štai valstybe் - turi. Turi ir aiškius aptvarus, ir struktūras, ir kasdienị profanišką (buitinị) šurmulį...

Išskirtinis socialinių mokslų bruožas - susitarimai. Priimtini jie kitiems, ar ne tai nuolatinių diskusijų dalykas. Iš karto teigiu: čia ir toliau pasiremsiu tautos suvokimu, kuris grindžiamas socialinès organizacijos bei sistemų teorijomis. Jos leidžia teigti, kad tautos (ir tautiškumo, nacionalumo) dèka kuriamas, saugomas ir kitoms kartoms, visam pasauliui perteikiamas ne bet koks, bet dvasinis kapitalas. Todèl tauta pirmiausia ir vertintina ne kaip gamintoju ir ne kaip vartotoju bendruomene, bet kaip šimtus ir tūkstančius metu kaupta dvasinio kapitalo saugykla. Tautai susirgus, jai išdūlejus ar ją sunaikinus, šis lobynas arba, kitais žodžiais tariant - dvasinių santykių tinklainè nunyksta. O žmogus jos narys? Jisai akis ị akị susiduria su kultūros ir civilizacijos skersvèjais.

Kažkas panašaus, siaubingo nutiko ne tik su mūsų artimiausiais lietuvių giminaičiais prūsais, garsẻjusiais ypač aukšta, turtinga dvasine kultūra. O paskui, praradus, užslopinus jų savastị, buvo priversti tenkintis klusnių landsknechtų ir baudžiauninkų vaidmeniu... Nemanau, kad nebus per daug nukrypta ị lankas pasakius, kad kažkas panašaus, nebepataisomo vyko (ir gal tebevyksta!) ir su lietuvių tauta. Argi neišryškèję jos vidinio irimo kontūrai? Juos galime matyti ir be padidinamojo stiklo? Argi šiandien neaišku, nesuprantama, kad, nunykus ir toliau nykstant prigimtinei kultūrai ir jos nešèjai tautai, nunyksta ir Moralinis Autoritetas? Argi nesiformuoja, nesiplečia erdvė Didžiajam Inkvizitoriui užimti dominuojančias pozicijas?

Po šių keletos ịvadinių minčių drąsiau galime pereiti prie anksčiau suformuluoto klausimo - prie kriterijaus, kuris palengvintų civilizacinio pajègumo ir civilizacinio neiggalumo supratimą. Prieš keliolika metų vienoje iš savo monografijų esu rašęs: kiekvienos tautos pagrindinis egzistencijos tikslas yra jos išlikimas ir kultūros bei civilizuotumo požiūriais visavertis evoliucionavimas. Pastarasis neịsivaizduojamas be laisvo, bet kartu ir tvaraus sąveikavimo su aplinkiniu pasauliu'. Šiandien vargu ar galéčiau ką prie tokios formuluotès pridurti. Ji grindžiama mąstymu apie tautos, kaip socialinio junginio, išlikimą ir jo tęstinumą; apie nuolat kintantị tautodaros, tautokūros, taip pat tautoardos, tautoiros procesus; apie tų procesų santykị ir to santykio vietą aplinkiniame pasaulyje.

Tauta toli gražu ne vien tik antropologinès kultūros, jos evoliucionavimo produktas. Ženklia dalimi ji yra ir gamtos „,išradimas“ - žmonių prisitaikymo prie gamtinių sąlygų būdas. Suprantama, kad evoliucionuojant civilizacijai, tobulèjant tech- 
nologijoms priklausomybès laipsnis nuo „natūros“ silpsta. Bet jokiu būdu neužgęsta. $\mathrm{Na}$, kad ir dèl gyvenamojoje teritorijoje suburtų ir telkiamų kolektyvinių socialinio veiksmo pastangų. Taip pat nenuginčijama, jog tautinis išskirtinumas (partikuliarumas) priklauso ne tik nuo teritorijoje egzistuojančio istorinio paveldo, bet dar ir nuo - žmogaus dvasinio, psichologinio ryšio su gamta, su landšaftu. Tą rodo vis labiau akcentuojamas demesys aplinkosaugai. Dar daugiau: visuotinai žinoma, gamta, jos ypatumai, net žemès sluoksnių sandara veikia, formuoja žmogaus antropologinius bruožus, ịskaitant ir elgsenos, temperamento niuansus.

Taigi, $\mathfrak{i}$ tautą tikslinga žvelgti kaip ị kultūros ir natūros produktą - tęstinị, civilizacijai gyvybingumą teikiantị šaltinị. Gal ir pasikartosiu... Bet tik dèl to, kad tikslinga atskirai pabrěžti: tautos visavertis evoliucionavimas pateiktoje jos egzistencijos pagrindinio tikslo apibrèžtyje suprantamas ne kaip egonacionalinis dèmesys sau, bet kaip gebejjimas dalyvauti civilizuotumo apykaitoje ir kurti bendrą visiems kultūros aruodą, i̇dedant savo partikuliarinę, t. y. savo tapatybès ženklu paženklintą, dalį.

V. Kavolis yra atkreipęs demesį $\mathfrak{t}$ japonų mokslininkès Takie Sugiyama Lebra pastebejjimą: japonų kultūroje centrinis yra sąveikinio reliatyvizmo principas, o Vakarų kultūrai, ypač JAV - būdingas vienakryptis determinizmas. „Japoniškasis principas", anot minètos autorès, reiškia, jog atskiri socialiniai vienetai sąveikai jungiasi ne akcentuodami savąsias individualizuotas pozicijas ir interesus, o darydami abipuses nuolaidas, visų pirma vadovaudamiesi visiems bendrais tautos, jos valstybès interesais. Tuo tarpu „vienakryptis determinizmas“ reiškia, jog patirties elementai atskiriami vienas nuo kito; jie priešinami, akcentuojama priežastingumo hierarchija. Visada yra, kas gali įsakyti, ir yra tie, kurie tą prisakymą privalo lojaliai vykdyti².

Šiose anksčiau minètų autorių mintyse galime pagauti skirtinga dvasia alsuojantị civilizuotumą. Bet... Šiuolaikiniame pasaulyje vis labiau, akivaizdžiau savo galias demonstruoja ir ịtvirtina vadinamoji tinklaveikos visuomenè. Beje, būtent jos dèka kultūrų ir civilizuotumo skirtybès niveliuojamos. Betgi kartu tinklaveikos visuomené platina ir užkratą - civilizacines negalias, t. y. civilizuotumą lydinčius šešèlinius palydovus.

Mąstant apie civilizacinị pajègumą, manau, protinga būtų laikytis principo: organizuojant socialinị pasauli, reiktų vengti mechaniško atkartojimo elementų, kurie yra paimti iš labiau nutolusios kultūrinès terpès. Kūrybiškas jų adaptavimas ir išskleidimas sustiprintų tautos, jos valstybès civilizuotumo visavertiškumą. Išrankiau elgiantis gali būti sustiprintas tautos tvarumas, jos egzistencinis prasmingumas, „pagerintas" santykis tarp tautokūros ir tautoardos. Ir, žinoma, - tuo pagausintas tautos įnašas ị žmonijos civilizacinị lobyną. Savaime suprantama, kad tokị vaidmenį tauta gali atlikti tik turèdama integralų (o ne besiblaškantį) valstybingumą ir lygiateisę ( $\mathrm{t}$. y. visavertišką) sąjungą su kitomis tautomis ir jų valstybėmis.

Nemanau, kad panašūs samprotavimai ir ypač anksčiau pateikta tautos egzistencijos tikslo apibrèžtis gali būti ženklinami retrogradiškumo (t. y. èjimo atgal) ženklu. 
Regis, kiekvienam mąstančiajam aišku, jog nūdienos pasauliui, prifarširuotam supermodernių technologijų ir visuotino triukšmo, vis dèlto trūksta egzistencinio prasmingumo akcentų. Tautos egzistencijos tikslo apibrèžtis būtent gali praversti kaip "prieinamas matas" sverti civilizuotumo laipsnị. Bet čia pat privalu akcentuoti tai, kad tautos ir jos valstybés egzistencijos tikslo siekis labai priklauso nuo abiejų šių sandų tvarumo bei integralumo savyje ir tarpusavyje.

Lietuva yra Europos Sąjungos narè. Valstybe privalo funkcionuoti pagal bendrą, t. y. Sąjungos, ritmą. Tačiau čia pat iškyla ịdomūs klausimai. Kodẻl asmuo, norédamas tapti „standartiniu“ europiečiu, privalo atsisakyti tradicinių šeimos, moralès, tautos ir net jos valstybės sampratų? Kodèl reikia perkratyti vertybių skalę, ịprastas tradicines skubomis keičiant ị naująsias? Gal praverstų visada turèti aiškesnị vaizdą ir apie tai, kas ir kaip tą lazdą perlenkia: Briuselyje ar Vilniuje? Argi tie, kurie disponuoja „lazdos lenkimu“, nesuvokia, kad tarp ịtaigiai peršamų vertybių esama ir tokių, kurios prisideda paversdamos žmogų bestubure, pilka medžiaga; suzombẻjusia būtybe?

Bet visa tai - jau atskira filosofija. Ir vis dèlto nesusilaikau nepacitavęs vieno iš pakankamai populiarių šiuolaikinių kritinio mąstymo autorių. Tai - vokiečių kilmès Horstas Kurnitzky'is . „Kaip tautų bendrumas Europoje yra redukuojamas iki vienos valiutos, taip ir pati visuomene „susitraukia“ iki ūkių sumos." Kitoje vietoje tą mintị autorius praplečia rašydamas: „Kai visuomenès samprata susiaurinama iki ūkio

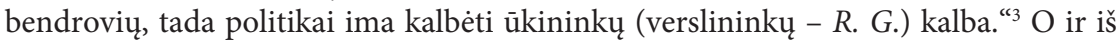
tiesų: ar ne tokias ir panašias kalbas šiandien girdime nuo ryto iki nakties?.. Dar kartą pacituosiu H. Kurnitzky'i . Jo nuomone, „Daugybė globalizacijos bijančių žmoniu [...] nemato, kad už uniformizmą ir kultūrinị bei ekonomini pasaulio nuskurdimą atsakinga ne globalizacija, o visa apimantis pelno siekio principas ir su juo susijusi kapitalo koncentracija. ${ }^{* 4}$

I H. Kurnitzky'i panašių autorių - gausybẻ. Be jų ir be kritinio mąstymo, be tos nuolatinès savistabos ir saviplakos, ko gero, tik greičiau imtų kalkèti žmonijos organizme pulsuojančios kraujagyslès.

Taigi, šioje studijoje civilizacinị pajėgumą autorius sieja su anksčiau ịvardintu pagrindiniu tautos egzistenciniu tikslu - visaverčiu evoliucionavimu. Tuo tarpu civilizacinį neiggalumą - su ịvairiais akivaizdžiai fiksuotinais esminiais nukrypimais nuo to tikslo. Apie tai toliau ir pakalbèsime.

\section{Civilizacinio neigalumo apibrèžtis}

Senesniais laikais (XIX-XX a. sandūra) Levas Tolstojus ir keletas kitų rusų rašytojų susigiminiavo sukurdami mąstančio mužiko Kozmos Prutkovo portretą. Jo lūpomis yra ištarta: „nelzja objat neobjatnovo“ (liet. - neįmanoma aprépti neaprè-

3 Kurnitzky, H. Necivilizuota civilizacija (Kaip visuomenè pralaimi savo ateiti). Vilnius: Dialogo kultūros institutas, 2002, p. 46.

4 Ibid., p. 156. 
piamo)... Daugelis filosofuojančių intelektualų tai supranta. Todèl ir socialinị pasauli bando suvokti ir aprašyti po gabaliuką. Betgi beveik visais atvejais tas gabaliukas, tapęs labiau pažintas, „praranda“ aiškesnes sąsajas su visuma.

Deja, mums - mirtingiesiems kito kelio neduota. Taip sakau, tarsi apsidrausdamas nuo galimų oponentų priekaišto už mano pasirinktą ižūloką poziciją.

Metaforiškai kalbant, civilizacinis neigalumas arba, kitais žodžiais - civilizuotumo negalia, tai - tautos antroji Mènulio pusè. Tai, šalia pozityvo, tautos istorijos vyksme susiformavęs ir įsitvirtinęs nepajègumas žengti koja kojon su kitų tautų ir jų valstybių žingsniuote - su tais, kurie yra atsidūrę civilizacijos priekyje ir, tarsi savaime, bendrai žingsniuotei diktuoja savo ritmą. Šiuo atveju galime kalbèti ir apie išskirtines tautos saviorganizavimosi ir ypač valstybinio tvarkymosi erdves, kurias užpildo toli gražu ne konstruktyvi visų jos subjektų veikla ir sąveika, ne nuoseklus iškylančių problemų sprendimas, bet vieno ar kito masto susipriešinimas: realiomis finansinèmis bei politinėmis galiomis disponuojančiu jègų suokalbiškumas (tylioji korupcija); nebaudžiamas nusikalstamumas; išminties stokojantys (strategiškai neapgalvoti) veiksmai, kurie sukelia tik papildomas sumaištis. Visa tai stabdo socialinę pažangą, prisideda prie socialinès aritmijos, anomijos sklaidos; didina visuomenės politinị socialinị nuovargị, užlaiko vadinamąją „klaidingą sąmonę“ ir pan.

Negebëjimas būti bendroje labiau civilizuotụjų „žingsniuoteje“ " pats savaime dar nieko nereiškia. Neiggalumas priklauso sisteminių reiškinių klasei. Visai negalvodamas apie civilizacinị neịgalumą, Emilis Diurkheimas dar XX a. pradžioje gana taikliai jị nusake viena sąvoka - anomija. I šią sąvoką jos autorius sudèjo socialinio gyvenimo nenormiškumą, ịsigalintị beteisiškumą, nesusikalbejjimą, susipriešinimą. Socialines erdves ir struktūras lengviau ima užvaldyti, užpildyti rutininiai, beprasmiai, niekam nereikalingi (išskyrus pačius sumanytojus) dalykai.

Ką visa tai reiškia intensyvejjančios raidos fone? O tai, kad tautos bei valstybès socialinèje organizacijoje ịsigali sisteminio, būtent sisteminio, chaotiškumo ir suokalbiškumo perviršis. Isigali voliuntaristinių pertvarkymų dominavimas - tų pertvarkymų, kurie esmingai pažeidžia stabilumo ir tęstinumo mechanizmus. Žinoma, neatmestinas nacionaliniame lygmenyje civilizacinio neigalumo blokavimas, kuris, pavyzdžiui, gli eiti ir eina iš Europos Sąjungos. Tačiau čia pat privalu pastebėti: kodèl santykiuose su savo nariais „Europos Centras" nusileidžia iki šilumos reguliavimo ir skaitiklio įrengimo kiekviename bute, tuo tarpu jo ịtaka nepakyla iki sakralių dalykų - iki žmogaus dvasinio gyvenimo, iki prigimtinès tapatybès puoselejjimo ir pan.? Ar tai nerodo, kad ir „Centrui“ būdingas vieno ar kito laipsnio civilizacinis neigalumas...

Kaip jau pastebejome, civilizacinis neịgalumas turi pačias ịvairiausias pasireiškimo formas. Viena iš jų - vadinamoji „klaidinga sąmonë“. Tai žmonių, atskirų socialinių segmentų, netgi valstybę tvarkančių struktūrų (institucijų) savivoka, jų žinios, kurios konstruojamos (kaupiamos ir praktikuojamos) spekuliatyviai, atplěštai ar kitaip izoliuotai nuo susiklosčiusios būsenos, nuo objektyvesnio realybès suvokimo. Neigalumas taip pat pasireiškia negebejjimu gaudyti netgi i artimiausias tolumas (ar erdves) nuvilnijantị savų sprendimų ir veiksmų negatyvųjị šešèlį, išgirsti jo aidą... Tai - refleksyvumo stoka. 
Nusileidus žemiau, iki žmonių elgsenos lygmens, prie civilizacinio neigalumo kontūrų reiktų priskirti ir anarchistinị individualizmą, ir servilizmą (įsiteikinèjimą stipresniajam), ir tokị reiškinị, kurị Z. Brzezińskis kadaise ịvardino kaip kornukopiškumą, t. y. žmonių gyvensenoje issišaknijusius juslinius poreikius; turtu, o ne išmintimi grindžiamos socialinès padèties, prestižo sieki $i^{5}$.

Civilizacinis neigalumas - tai tautos istorijoje susiformavęs sindromas, stigma. Toji stigma įsitvirtina kaip išorinių ir vidinių aplinkybių samplaika, jos rezultatas; kaip trikdis visaverčiam tautos ir jos valstybès evoliucionavimui. Kai kalbame apie civilizacinị neiggalumą, tai jokiu būdu nereiškia jo suabsoliutinimo, jo nepažeidžiamumo. Pažanga, brandus civilizuotumas gali būti (ir būna) visai šalia. Bet ji reikia išmintingai, nuosekliai „gaudyti“. Ir - atsakingai organizuotis.

Ar esama Lietuvoje veiksmingų rezervų, kurie ir valstybei, ir tautai suteiktų didesnị integralumą? Kurie būtų nebrangūs ir visiems prieinami bei suprantami? Taip, tokių rezervų tikrai yra. Apie vieną iš jų glaustai ir pakalbėsime.

Mūsų šalis - piliakalnių kraštas. Jų tinklas išpintas šimtais ir net tūkstančiais mazgų. Štai Kriūkų seniūnijoje (kuri randasi anapus Nemuno, priešais Veliuoną), palei upę stūkso net šeši piliakalniai. Nedidukai. Jų supylimas datuojamas X-XI amžiais. Kam jie buvo skirti? Kryžeivių dar ir kvapo nebuvo... Daugiau negu aišku, jog absoliuti dauguma Lietuvos piliakalnių buvo skirti ne gynybai, bet visai kitiems reikalams. Kokiems? Atsakymą viešai teikiu ne pirmąkart... Pagal anų laikų papročius ir reikalavimus greičiausiai kiekvieno kaimo bendruomenė privalèjo turèti savo piliakalnị - šventyklą, apeigų ir bendruomenès sakralinio susibėgimo centrą. Tikètina, jog piliakalnių dèka suklestejjo bendruomenę rišanti, tegu ir kanonais dvelkianti, dvasinė kultūra. Metaforiškai ją galètume ịvardinti kaip sutartinių kultūrą. Tai - tautos dvasinis lobis... O ką aptiksime i piliakalnių tinklą žvelgdami grynai pragmatinio jų tikslingumo žvilgsniu? Jų dẻka susiformavo itin stabili, tarp savęs sąveikaujanti sistema, kuri pateikè savo produkciją: užgimé, įsitvirtino lietuvių tauta ir jos valstybė...

Apibendrinsime. Reikia visai nedaug. $\mathrm{Na}$, kad ir $\mathrm{N}$ metus paskelbti piliakalniu istorinio, fizinio ir dvasinio atgaivinimo metais. Reiktų gal tik keleto milijonų eurų, kad visos seniūnijos, visos kaimo bendruomenès ir visos mokyklos subrustų tvarkyti piliakalnius, didžiuotųsi savo pašoneje esamu neįkainojamu turtu. Mąstytų apie tai, koki dar, be istorinès atminties, galima būtų jiems suteikti funkcionalumą. Na, ir prieš Europą galètume pasididžiuoti savo pačių užmirštu, bet vèl prisimintu ne tik materialinès, bet ir ypač dvasinès kultūros lobynu...

\section{Civilizacinis neigalumas Lietuvoje: nūdienos bruožai}

Iki šiol apie civilizacinio neigalumo Lietuvoje kontūrus kalbejome palyginti aptakiai. Dabar gi pabandysime juos labiau apibrèžti. Bet ir čia nenusileisime iki konkrečių pavyzdžių ar atvejų aprašymo. Kritinio pobūdžio apžvalgèlè grindžiama gau- 
siomis ịvairių autorių publikacijomis, mass media teikiama informacija, ịvairiomis viešomis diskusijomis, atsakingų asmenų („valstybininkų“) dažnais pasisakymais ir pan. Manau, kad toji civilizacinio neigalumo (antrosios mènulio pusès) konstrukcija nesunkiai gali būti „pagaunama“ kiekvieno aktyvesnio piliečio.

Toliau teikiamas formuluotes - ypač lakoniškai suformuluotus apibendrinimus siūlytume įsivaizduoti kaip statybines plytas, kaip blokelius, kurių „dèka“ ši konstrukcija išnyra iš socialinès istorijos ir dabarties ūkų ir stūkso savaip darkydama mūsų šalies peizažą. Šiai sociosofinio, politologinio pobūdžio apžvalgai imsime dvi erdves. Pirma, tai bendros socialinès elgsenos erdvé (kuri artimesnè ją tapatinant su visuomene, su lietuvių tauta). Antra, tai - valstybès organizacinè kultūra, arba valstybès struktūrų vadybinès elgsenos erdvè.

Būta autoriaus bandymų civilizacinio neịgalumo kontūrus vienu ar kitu pavidalu išskleisti asmens, individų lygmeniu. Anuo atveju demesys buvo fokusuojamas i vadinamąją deformuotą asmenybę. Buvo išskleistas (ir sociologiniais stebejimais grindžiamas) tokios asmenybés bendrasis portretas, išskirti jo potipiai, taip pat aptarti tų potipių sklaidos nūdienos Lietuvoje kontūrai ${ }^{6}$. Šiuo atveju dèmesį kreipsime $\mathfrak{i}$ aukštesnị, bendresnị lygmenị - $\mathfrak{i}$ šalies socialinejje organizacijoje ịsitvirtinusius civilizacinio neigalumo bruožus.

\section{Bendros socialinès elgsenos erdvé}

- ̨̇sitvirtinusi slinktis ị skaidymąsi, diferencijavimąsi, ị priešpriešą, o ne jungtị, bendro intereso akcentavimą;

- polinkis ị monologinę (geriausiu atveju - ị dialoginę), o ne poliloginę bendravimo ir bendradarbiavimo manierą; aiški konsensinès (pilietinès) kultūros ir jos skatinimo stoka;

- polinkis ieškoti negatyvo, kritikuoti, kompiliuoti (išlikti stebètojo pozicijoje); per menkas dèmesys kuriamajai veiklai, pozityviam darbui;

- bendruomeninio sugyvenimo nuvertejjimas (devalvacija), individualistinių bei siauragrupinių (egocentristinių) interesų akcentavimas; pilietinio organizuotumo, pilietinès saviteigos stoka ir sąlygų jai stygius, lengvinantis kriminalinès agresijos, nusikalstamumo sklaidą;

- gamtos kaip sakralaus pasaulio pajautos praradimas, kartu - ir prigimtinès tapatybès nunykimas;

- globalizacijos plètrai neadekvatus tautinio (nacionalinio) sąmoningumo ir ypač valstybinio patriotizmo nuvertẻjimas - tų reiškinių atsispindẻjimas ženklios dalies jaunosios kartos elgsenoje.

Kritinị pokalbị apie civilizacinį neiggalumą, žvelgiant ị bendrą tautos (visuomenès) elgseną, galètume pratęsti. Bet, manau, ir to, ką pasakème, pakanka bendros konstrukcijos vaizdui. Na, o toliau išdėstytų blokelių (plytų) įvardinimas bus gauses-

6 Grigas, R. Tautos kokybinio virsmo atvejis: deformuotos asmenybės potipių sklaida Lietuvoje. Socialiniu moksly studijos. 2013, 5(4): 997-1009. 
nis jau vien dèl tos priežasties, kad būtent valstybès apdare civilizacinis neigalumas būna ryškesnis, visiems matomesnis.

\section{Valstybès vadybinès elgsenos erdvé}

- socialinès tvarkos palaikymas apeliuojant ì formaliąją organizaciją (teisèkūrą, teisésaugą, represinị aparatą ir pan.), o ne ị bendruomeniškumą, ne ị reguliuojamąją kultūros misiją; biurokratizuotas valdymo ịsigalejjimas ir valdininkijos nebaudžiamumas (prasiveržiantis suokalbiškumu);

- savanaudiškų segmentų ir struktūrų, sisteminės (ypač politinès) korupcijos valstybės tvarkyme ịsitvirtinimas;

- visuomenę demoralizuojantis atotrūkis tarp objektyvaus teisingumo ir praktiškosios, t. y. funkcionuojančios normatyvinès, teisès, įtvirtinantis amoralumo pozicijas;

- valstybinių strateginio pobūdžio sprendimų nevisavertiškumas, chroniškas jų vẻlavimas, pasireiškiantis dar ir biudžetinių lèšų švaistymu;

- tautos, kaip valstybès suvereno ignoravimas, taip pat ir pačios valstybès atsipalaidavimas (priešlaikinis nunykimas) išlaikant savo suverenitetą; visuomenès susipriešinimo su valstybe, netgi su pačia valstybingumo idèja perviršis;

- diagnostinès, refleksyviosios mąstysenos bei refleksyviosios (priimtų sprendimų atgarsius gaudančios) stebėsenos stoka;

- moderniosios, bet aiškesniu autentiškumu (partikuliarumu) pasižyminčios nacionalinès saviteigos, nacionalinio orumo valstybės organizavime nepakankamumas; tautos (ir jos valstybės) tęstinumą užtikrinančios ideologijos stygius.

Šių eilučių skaitytojas autoriaus pateiktas, gal ir įžūlokas formuluotes neturètų priimti ir vertinti kaip teisejjo verdiktą... Panaši saviplaka turètų būti priimama kaip gydomasis ar kaip profilaktinis vaistas nuo kraujagyslių kalkejjimo. Na, o kalbamuoju atveju - nuo tautos ir jo valstybės pakankamai akivaizdžių pasiligojimų.

\section{Civilizacinès ịtampos ir jų raiška}

Gal ir pasikartosime pastebėdami, kad aukščiau ịvardinti civilizacinio neigalumo kontūrai, jų samplaka ir sklaida lemia vadinamųjų civilizacinių ịtampų laukus, jų pasireiškimo laipsnị. Vyt. Kavolis (vienas iš civilizacijų lyginamosios teorijos pradininkų) yra išskyręs keletą universalumu pasižyminčių ịtampų, kurios mūsų plètojamos temos kontekste galètų sudominti skaitytoją. Tai įtampos, kurios reiškiasi tarp:

- kontrolès ir išsilaisvinimo;

- internalizacijos ir eksternalizacijos;

- racionalumo ir virtualumo;

- susisaistymo ir atsijungimo;

- empirikos ir transcendencijos;

- hierarchijos ir lygybès; 
- natūralumo ir dirbtinumo;

- universalumo ir partikuliarumo;

- praeities ir ateities;

- plètimosi ir stabilizacijos?

Vèliau šias įtampas V. Kavolis pavadins intelektualinèmis priešingybėmis. Šis autoriaus pastebejjimas, man regis, yra gana reikšmingas. Iš tiesų, mes tik savojo „proto mankšta" galime susigaudyti socialiniame pasaulyje, kuris žmogaus receptoriais nepagaunama, nematoma (latentine) puse gali būti prilygintas džiunglių pasauliui...

Pratęsime didžiųjų priešpriešų (dichotomijų) įvardinimą. Jau vien dèl to, kad jos gali būti vertinamos kaip sociumo raumenų skaidulos, nervų sistemos raizgalynè. Kitais žodžiais, priešpriešų pažinimas - tai socialinès organizacijos anatomijos pažinimas. Taigi, prie to, kas V. Kavolio ịvardinta, galima pridurti dar ir tokių socialinio vyksmo krypčių susidūrimus, kurie ịsitvirtina taip:

- kūrimo ir griovimo;

- chaoso ir tvarkos (entropijos ir negentropijos);

- individualizmo (grupizmo) ir bendruomeniškumo;

- hedonizmo ir asketiškumo;

- tautos ir valstybės (paryškinta sąmoningai) ir t. t., ir pan.

Anot V. Kavolio, jo įvardintos (ir, žinoma - jo neįvardintos) priešingybės išsiskirdamos, judèdamos priešingomis kryptimis, gimdo civilizacijos (civilizuotumo) krizes. Šis mąstytojas teigia, kad krizè atsiranda tada, kai tarp priešingybių nèra kontakto, komunikacijos. „Tada kultūra suskyla, joje galbūt netrūksta energijos, judèjimo, bet nèra kas tą judèjimą jungtų i bendrą procesą, kiekviena dalis eina sau, bet nèra to, ką pradedam vadinti kultūriniu polilogu (paryškinta mano - R. G.). ${ }^{\text {"8 }}$

Tačiau... Išsilakstančius, išsibarstančius, tarp savęs nebesutariančius, netgi nebekomunikuojančius segmentus gali susaistyti ne bet koks „molis“. „Jungiamosios medžiagos" paieška ir jos panaudojimas - aukščiausios prabos dalykas. Ta medžiaga lemia ir tautos, ir jos valstybés likimą. Ir - kiekvienos iš jų indèli ̣ i bendrąj visuotinès kultūros ir civilizuotumo aruodą. Vieną iš to „rišamojo molio “ atmainų esame pateikę - tai be adekvatesnio dèmesio tolesniam „trūnijimui“ paliktas piliakalnių tinklas. $\mathrm{Na}$, o platesni pamąstymai apie „rišamąją medžiagą" būtų jau kito, suprantama, nūdienai ypač aktualaus pokalbio tema.

\section{Epiloginès mintys}

Civilizacinio neigalumo įvardinimas ir juolab jo adresavimas lietuvių tautai ir jos valstybei gali būti priimamas ne kaip tikras pinigas, o kaip tam tikrus realybės kontūrus nužyminti intelektualinè konstrukcija. Postmodernios visuomenès tyrinètojas J.-F. Lyotardas panašius tekstus greičiausiai pavadintų žaidimu „žodinėmis konst-

7 Kavolis, V. Civilizaciniai procesai ir šiandieninè Lietuva. Kultūros barai. 7: 3.

8 Kavolis, V., supra note 2, p. 220-221. 
rukcijomis“, kurios visuotinai ịsigali žmonių mąstyme ${ }^{9}$. Betgi ar be jų, tokių konstrukcijų mes sugebėtume susigaudyti socialiniame pasaulyje? Kiek ir ko iš to pasaulio su „žodinèmis konstrukcijomis“ atkapstome ir ịforminame, tiek su tuo pasauliu mes turime ir reikalų... Jeigu mes nežinome to pasaulio šešèlinių pusių, vadinamųjų „juodųjų skylių“, juolab jeigu dar ir nenorime žinoti - praradimai būna skaudūs. Mes negalime tam pasauliui būtent adekvačiais veiksmais ir organizuotis?

Atskira kalba būtų ne tik apie šešèlinio pasaulio (antrosios Mènulio pusès) pajautos, pagavos laipsnị, bet ir apie poreikị bei paskatą tokiais darbais užsiimti.

I lietuvių tautos ir jos valstybės civilizacinị neigalumą pabandème žvelgti suformulavę tautos egzistencijos pagrindinio tikslo imperatyvą. Tikètina, kad tokia autoriaus pozicija ne vieno oponento bus vertinama kaip retrogradiška, konservatyvi ar „nacionalistiška“. Tačiau autorius, skirtingai nei oponuojantysis, ị Europos Sąjungą žvelgia kaip ì gyvybingą sąveikaujančių tautų ir jų valstybių puokštę, o ne ị kaip merkantilizmu, supranacionalumu (antitautiškumu) alsuojančią imperiją. Siūlomas izžvalgos aspektas, manau, turi teisę egzistuoti šalia kitų, nepretenduodamas ị visažiniškumą.

Tačiau, kaip autorius, būčiau nenuoseklus, jeigu nepastebėčiau, kad ES projekte esama to, kas gali būti vertinama kaip civilizacinio klaidingumo bruožas. Nèra aiškaus atsakymo, kodèl siekiant Sąjungos integralumo kartu siekiama neutralizuoti ne tik politinị, bet ir kultūrinị, ypač tautinị partikuliarumą (išskirtinumą, gyvybingumą). Kodèl vengiama tautiškumu grindžiamos tapatybès? Toks susirūpinimas, kaip žinome, iškyla tik neskaitlingoms, istorijos skaudžiai maigytoms tautoms. Bet jis neaktualus vokiečiams ir prancūzams, italams ir mūsų kaimynams lenkams...

ES atsakingų vadovų: J. M. Barroso, H. van Rompèjus, A. Merkell ir kitų vizijose tauta, jos tęstinumo puoselejjimas turètų netekti ne tik politinio subjekto statuso, bet ir sentimentų. Tautos pagrindu susiformavusi kolektyvinè tapatybè turi būti keičiama atskirų individų, grupių (ir net lytinių mažumų) tapatybėmis. Europos Sąjungos pilietybe், anot jų, privalo tapti viršesne už nacionalinę tapatybę. Po Lisabonos sutarties vis labiau griežtinamas ES ịstatymų ir Konstitucijos taikymas... Gal tai pastanga, projektas, grindžiamas JAV modeliu? Betgi jisai sterilus nuo tautų istorijos ir kultūrų tradicijos! Jis palankus ir pritaikytas rinkos fundamentalizmui, vartojimo visur ir visko kultūrai!

2014-ųjų metų rinkimai ị Europos Parlamentą parodè susirūpinimą tautinių tapatybių, tradicinių vertybių likimu. Tikètina, kad bus pozityvių pokyčių ir ES integracijos politikoje. Taip pat tikètina, kad ir Lietuvoje tokie pokyčiai, jų tendencijos bus aiškesnès. Jau dabar pakankamai aiškus, subrendęs teorinès minties „užsakymas“, kuris atitiktų pageidautinus pokyčius, kurie neprieštarautų ES integracijai, bet kurie kartu sustiprintų jos narių vidinị integralumą. Šiame kontekste civilizacinio neigalumo bruožų išryškinimas ir jų blokavimas - vienas iš pamatinių rūpesčių ne tik politikams, bet ir mokslininkams. 
Šio straipsnio autorius ne kartą vienu ar kitu aspektu yra bandęs plètoti sociosofinę mintị aptariamos problematikos kryptimis ${ }^{10}$. Betgi mes, rašantieji, aiškiai suvokiame: veiksmas labai dažnai būna atskirtas nuo minties. Veiksmą kur kas didesniu laipsniu nei mintị lemia galbūt tas pats nelemtasis, ị prigimtị ịsigèręs civilizacinis neiggalumas. Užburtas ratas? Taip... Neįgalumas ilgainiui ịgyja legitimizuotą pavidalą - su juo apsiprantama, panašiai kaip žmogus apsipranta su savo senatve...

Tautos irgi sensta. Istorijos skersvejjų yra išpūkštomos...

\title{
Literatūra
}

Brzeziński, Z. Nebevaldomas pasaulis. Vilnius: Tvermè, 1998.

Grigas, R. Tautiné savivoka. Vilnius: Rosma, 2001.

Grigas, R. Tautos kokybinio virsmo atvejis: deformuotos asmenybès potipių sklaida Lietuvoje. Socialiniu moksly studijos. 2013, 5 (4).

Kavolis, V. Civilizaciniai procesai ir šiandieninè Lietuva. Kultūros barai. 7.

Kavolis, V. Kultūros dirbtuvé. Vilnius: Baltos lankos, 1996.
Kavolis, V. Kultūros dirbtuve. Vilnius: Baltos lankos, 1996.

Kurnitzky, H. Necivilizuota civilizacija (Kaip visuomenè pralaimi savo ateitį). Vilnius: Dialogo kultūros institutas, 2002.

Lyotard, J.-Fr. Postmodernus būvis (šiuolaikinị žinojimą aptariant). Vilnius: Baltos lankos, 1993.

\section{DISABILITY OF CIVILISATION AND ITS EVIDENCE IN LITHUANIA}

\author{
Romualdas Grigas \\ Lithuanian Academy of Sciences, Lithuania
}

Summary. The article's attention is focused on one of the most serious social and political organizational problems - the so-called disability of civilization - and on the features of the spreading of this phenomenon in Lithuania, and the Lithuanian nation. The author's own interpretation of the disability of civilization is seen as the nation and the nation based state's areas of behavior, which are filled with excessive polarization, deviance, shady economy, crime and actions lacking wisdom and/or continuity (and,

10 Štai kelios mano monografijos, kuriose vienu ar kitu laipsniu yra kalbama apie lietuvių tautos socialinès organizacijos būvị ir jos gyvenimą: Socialiniu ịtampu Lietuvoje laukai. Vilnius, 1998, 186 p.; Sociologine savivoka. Vilnius: Rosma, 2001, 234 p.; Tautine savivoka. Vilnius: Rosma, 2001, 292 p.; Senieji lietuviai: tapatybés bruožai ir ju likimas. Vilnius: Edukologija, 2009, 302 p.; Lietuvių tautos išlikimo dramos. Vilnius: Diemedis, Versmè, 2013, 560 p. 
therefore, strategically unplanned). Social disability promotes the scattering of anomies, social arrhythmias and social fatigue, consequently giving birth to and supporting the so-called "false consciousness", etc.

The author believes that a disability of civilization is not a distinctive feature of any nation. However, in each country it has its own idiosyncrasies, determined by its historical legacy, its relationship with today's world and with globalization overshadowing it. The author also draws attention to Lithuania's approach towards a meaningful relationship with the EU.

Keywords: capacity of civilization, disability of civilization, social organization, formation of a nation, decay of a nation.

Romualdas Grigas, Lietuvos mokslų akademijos narys emeritas, habilituotas socialinių mokslų daktaras, profesorius. Mokslinių tyrimų kryptys: socialinė filosofija, socialinė antropologija, sociologija (socialiné organizacija, socialiniai procesai), lietuvių tautos socialiné organizacija ir jos sociodinamika.

Romualdas Grigas, Lithuanian Academy of Sciences, Fellow Emeritus, Habilitated Doctor of Social Sciences, Professor. Research interests: social philosophy, social anthropology, sociology (social organization, social processes), Lithuanian nation and its social organization's sociodynamics. 